\title{
THE CHANCES OF POLISH CONTEINER TERMANALS FOR WINNING CARGO AND SERVICES ROUTE CHINA-EUROPE-CHINA
}

DATA PRZESŁANIA: 02.09.2017| DATA AKCEPTACJI: 12.10.2017| KOD JEL: L92, R41

\author{
Józef Perenc \\ Wydział Zarządzania i Ekonomiki Usług, Uniwersytet Szczeciński \\ jozef.perenc@wzieu.pl
}

\begin{abstract}
In the modern world, in Europe and in Poland there can be observed many forms of cooperation between states and enterprises. Many business entities take a lot of effort to offer the most up-to-date services and to prepare sales and marketing networks ready to win on competitive market. These processes affect transport market as well.

The article focuses on global transport services, in particular the competition for international cargo traffic in China-Europe route. It is presented on the background of the globalization and competitive processes in transport services. The demand for transport services, resulting from rapid growth of China is discussed, with particular interest in two modes of transport: railway and sea. The article considers the conditions for China-Europe rail transport due to the recent initiatives towards building the "Silk Road". It opens new possibilities for rail transport to compete on the China - Europe route, especially considering the factor of time. The conclusions present the guidelines for further development on the transport services on the China-Europe route.
\end{abstract}

KEYWORDS rail transport, sea transport, competition, globalization

\section{INTRODUCTION}

In the modern world, in Europe and in Poland there can be observed many forms of cooperation between states and enterprises. Many business entities take a lot of effort to offer the most up-todate products and services and to prepare sales and marketing networks ready to win on competitive market. There can be observed the emergence of global actors and networks of manufacturers who want to win the international competition through efficient and effective transport systems. In this global expansion the European Union continues to play an important role but on the market we have seen a considerable activity of China's economy for many years. Therefore, the article focuses on global transport services, in particular the competition for international cargo traffic in China-Europe route. 


\section{CHALLENGES OF MODERN GLOBALIZATION}

Globalization is distinguished as a particular mega trend in the modern world economy. J. Naisbitt (Naisbitt, 2007), during the constructing of megatrends, stated that many economies from the national approach tend to global economy, to internationalization. Globalization is a specific, contemporary dimension of the global economy. Our world is becoming one market. The global economy is developing on the basis of liberalization of economic activity, due to the deregulation of national economies and the increasingly limited role of national states. Due to these processes of opening markets, scientific and technological progress, the processes of economic integration of many regions and states there are progressing the process of globalization, the processes of greater coordination of economic activity (Kuciński, 2005). Thanks to these processes there can be minimized the production and transaction costs, making it easier to access the world market.

Economic integration processes can be particularly noted within the European Union and its subsequent enlargements in 1973, 1981, 1986, 1995, 2004, 2007 and 2013. These processes intensified, according to E. Załoga (Załoga, 2013), the process of globalization.

The transport services play an important role in globalization. With the ever-increasing means of land, air and sea transport, the distance between countries, companies and people is reduced - and the world is getting smaller and smaller. Many world economists indicate that globalization is a close integration of states and people in the world, resulting in huge reductions in transport costs, resulting in the removal of many barriers to the flow of goods, services, capital and knowledge. Due to the globalization caused by technical, social, economic and political forces, it is possible to use the forces of globalization to reduce the barriers to global transport development and the progressive economic expansion. Globalization is conducive to increased inter-branch competition (Rosa, 2013). The distance of thousands of kilometers can be easily covered thanks to transcontinental rail lines, the maritime shipping routes and a dense network of air connections. Globalization fosters the development of the transcontinental infrastructure network, imparts new quality standards in many transport sectors, is the source and driving force of technological and technological progress in transport, creates specific preferences for the desired market structure, leads to the development of modern information systems and contributes to the construction of modern and efficient logistics networks. Globalization and integration contribute to the increased competition and the improvement of free, unrestricted trade (in the world, in Europe and in Poland). These processes cause an increase in demand for long-haul transport services and the need for increased availability of these services.

\section{CHINA AS THE "MOTOR" OF THE WORLD ECONOMY}

Over the past years, China's economy has developed at a rate of 10-11\% of GDP growth per year. However, from 2015 and in 2016, a slowdown in the country's growth rate to 7\% of GDP could be observed. The Chinese government is undertaking a great deal of actions to stimulate domestic demand. Among other things, by the end of 2016, there was the reduction of the half of the tax for new car up to 1.6 engine capacity as well as there was a launch started and many lines of credit were used to purchase housing - $30 \%$ to $25 \%$ of their own contribution to high interest loans was raised to stimulate demand for housing, especially in small Chinese cities. Banking experts from 
Stanford Bernstein criticize central Chinese authorities for too late activation of incentives and financial stimulus - both for businesses and individuals.

China's export expansion is an important part of world trade. By the end of 2016, China's trade in land and sea had a turnover of $€ 559$ billion from Europe (180 billion from Germany), ASEAN (Association of South-East Asian Nations) - $€ 443$ billion, Middle East - 257 billion, Africa 192 billion, CIS (Commonwealth of Independent States) - 150 billion USD. In European trade, the share of China's trade with Poland is very small - as shown in Table 1.

Table 1. Imports and Exports of Products between Poland and China (USD billions)

\begin{tabular}{|c|c|c|}
\hline Years & Import to Poland from China & Export from Poland to China \\
\hline 2012 & 13.7 & 1.36 \\
\hline 2013 & 14.6 & 1.60 \\
\hline 2014 & 17.6 & 1.70 \\
\hline 2015 & 20.5 & 1.82 \\
\hline 2016 & 19.8 & 1.54 \\
\hline
\end{tabular}

Source: Godusławski (2017).

It is clear from the table in Table 1 that the Polish economy should pay more attention to boosting exports to China and better balancing the trade with this economic power.

\section{TRADE OF CHINA WITH EUROPE}

The ongoing processes of economic integration and globalization contribute to the growth of world trade and to increased competition for entities and countries that play an important role in the export and import of the products and services traded. Changes in world trade have an impact on changes in demand for transport services as well. The specific volume of demand is related to the preferences of customers to shape the supply of services and, on the other hand, increases the availability of those services. EU countries (28) have the largest share in world foreign trade. The volume of exports and imports of EU countries in the past years was higher than exports and imports of US. The turnover of trade of chosen largest participants in world trade is shown in Table 2.

Table 2. Chosen biggest turnovers in the world trade in the years 2010-2015 (USD billions)

\begin{tabular}{|l|l|l|l|}
\hline \multicolumn{1}{|c|}{ Export, including: } & 2010 & 2014 & 2015 \\
\hline EU (28) & 1794 & 2010 & 1985 \\
\hline China & 1758 & 2342 & 2275 \\
\hline USA & 1278 & 1621 & 1505 \\
\hline Japan & 770 & 684 & 625 \\
\hline South Korea & 466 & 573 & 527 \\
\hline Russian Federation & 401 & 498 & 340 \\
\hline \multicolumn{1}{|c|}{ Import, including: } & & & 1682 \\
\hline EU (28) & 1790 & 1959 & 1682 \\
\hline China & 1396 & 1959 & \\
\hline
\end{tabular}




\begin{tabular}{|l|c|c|c|}
\hline \multicolumn{1}{|c|}{ Import, including: } & 2010 & 2014 & 2015 \\
\hline USA & 1969 & 2413 & 2308 \\
\hline Japan & 694 & 822 & 648 \\
\hline South Korea & 425 & 526 & 436 \\
\hline Russian Federation & 249 & 308 & 194 \\
\hline
\end{tabular}

Source: International Trade Statistic 2010-2016, www.wto.org (10.02.2017).

The above table clearly shows that the EU was the first to dominate the world's exports of goods with a share from $11.7 \%$ to 15.3 in 2014 , followed by China with $17.4 \%$ in 2015 . Stable second/ third share in global trade is taken by the US, which share has grown from $8.4 \%$ in 2010 to $11.5 \%$ in 2015. Slightly less than the top of the global exports are Japan, Korea, Russian Federation with about $2.6-4.8 \%$.

Similar proportions and trends are occurring in world imports, where two US and China countries have a similar share of world trade in imports - first in 2010 with US $12.7 \%$ and China - 9.0\% and in 2015 US and China has reached 17.3\%. US, China and the EU (28) have strong economies oriented towards foreign trade; their finances, strategies for opening up their economies to innovative foreign products, participation in world trade organizations allow them to use foreign trade to further systematically develop their economies and to boost these manufacturers whose products are sought around the world.

\section{FROM TRANS-SIBERIAN RAILWAY TO THE "SILK ROAD"}

Countries such as China, Korea, Japan and Russia are increasingly involved in world trade. At the end of the twentieth century, China accounted for around $4 \%$ of global world trade. And in the years 2010-2015 this share increased to about 7\%. Much of China's exports and imports are carried out using containers, maritime transport and recently also by using the European and Asian rail network. One of the important components of the international railway network is the Trans-Siberian Railway with a line length of $9822 \mathrm{~km}$. The scheme of this line is illustrated in Figure 1. Trans-Siberian line was built at the end of the 19th century. It is now fully electrified, with dual track and is fully equipped with modern railway control devices. The line is placed with very difficult terrain conditions and difficult weather conditions. It plays an important role in long-haul passenger and freight traffic. Many authors, including A. Lipińska-Słota (2009), emphasize the natural resources of this area (coal, oil, wood and natural gas).

The Trans-Siberian Railway is a natural extension of the second transport corridor in relation to Berlin-Warsaw-Moscow-Nizhny Novgorod and further to Vladivostok, Nachodka, Vostochny and Posiet. This line is the basic component of the railway infrastructure connecting East Asia countries, i.e. Japan, China and Korea to Central and Western Europe. The main advantage of this railway is the significant shortening of delivery time, especially in containers from China, Korea and Japan to customers located in Germany, Poland, Slovakia, Finland and other countries. The delivery time of cargo (including containers) by rail from East Asia to Lodz, Sławków or Hamburg varies from 14 to 20 days. On the other hand, the main disadvantage for senders and receivers is the cost of transporting a container that varies between $\$ 9,000$ and $\$ 10,000$ per one 20 feet 
container (TEU) container. Much more favorable is the price of sea freight which for one TEU container varies from 1100 USD to about 1990 USD for one TEU container (Pluciński, 2013; Grzybowski, 2015). Another disadventage of the Trans-Syberian Railway is the necessity of reloading containers and other cargo at border stations with the change of track gauge from $1524 \mathrm{~mm}$ to $1435 \mathrm{~mm}$. The idea of using variable gauge system (for instance SUW 2000 type, developed by Ryszard Suwalski) is more applicable to passenger transport. However, the current transshipment potential of Polish and Belarusian railways on the eastern border of Poland is sufficient. Małaszewicze, Brest, Sławków and other border railway stations are fully prepared for the efficient and rapid reloading of containers for standard gauge platforms and for comprehensive cargo handling in the connections of Europe and East Asia.

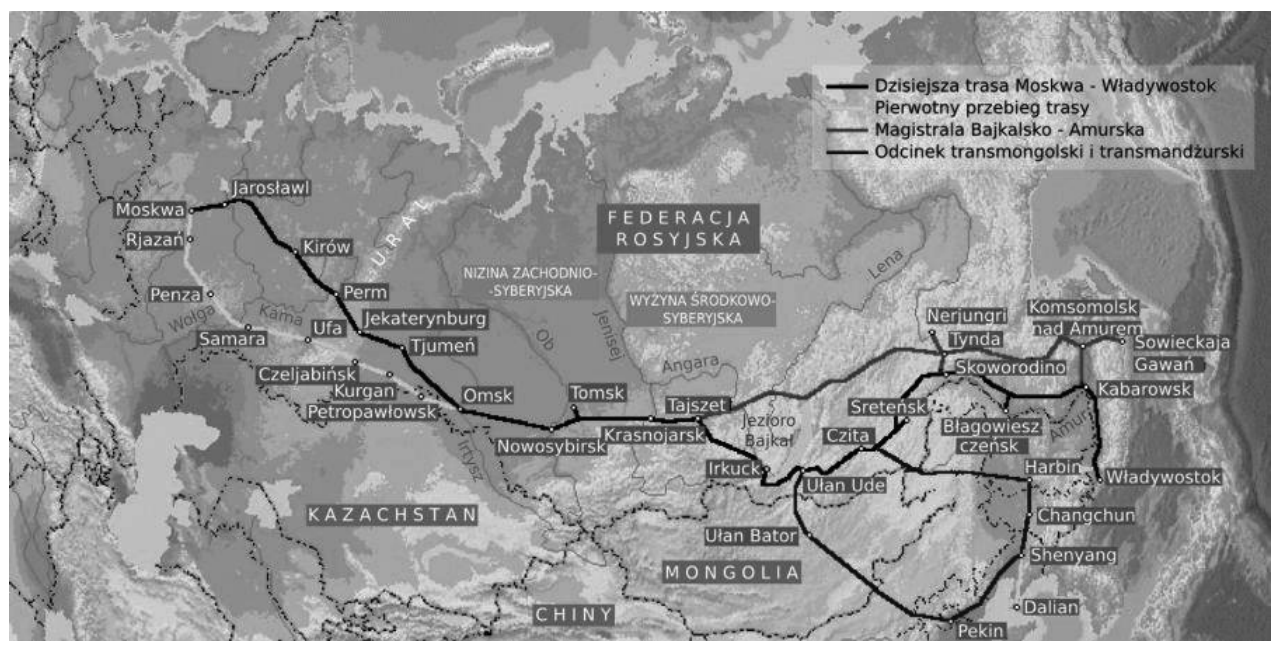

Figure 1. The route of The Trans-Siberian Railway

Source: http://www.strangehistory.net/2014/12/08/devil-trans-siberian-railway/ (2017.12.21).

\section{"SILK ROAD" - A CHANCE TO ACTIVATE LAND TRANSPORT BY RAIL FROM CHINA TO EUROPE}

According to information obtained from DHL's logistics division in Shanghai in 2014, there was a $200 \%$ increase in the number of containers transported by the railroad between China and Europe comparing to previous years. It is a very positive signal and it gives hope that such a trend will continue in the years to come. There can also be noticed the fuller utilization of the capacity of the Trans-Siberian Railway. There is an increasing need for a new, so called southern route, connecting the the provinces of China: Chengdu, Wuhan, Zengzhu with Moscow, Małaszewicze, Łódź, Duisburg, Hamburg and other cities. In 2014, several Chinese cities launched connections with Europe from cities such as Chogging, Chengdu, Suzhou - the so-called "western corridor" as a link between China via Kazakhstan, Russia, Belarus and Poland to Germany (see Figure 1). In Poland, the destination stations on this route can be Sławków and Łódź (both as destination stations or hubs for further expedition of cargo in containers). 
This "Silk Road" can be beneficial for Polish railway and car carriers as well as for logistics companies. This new route through Kazakhstan creates many problems at some border stations and due to the dictation of prices by Russian rail for access to Russian railway infrastructure. On the other hand, the financial support provided by Chinese railways and operators at Chinese container terminals is a very positive sign. Financial support from local Chinese governments, favorable loans, financial support for China's container terminals and the growing interest of international financial organizations such as the EIB, EBRD and WB in initiatives for the "Silk Road" contribute to growing opportunities for the development of China's new connection with Central And Western Europe. It is estimated that due to the "Silk Road", Poland can function in the midst of these transformations and processes. Thanks to this combination there will be possible to increase export of Polish products to China; apart from copper from the Lubuskie region, there will be possible growth in the export of food, meat, dairy products and vegetables. This new route has been promoted by the Chinese administration of president Xi Jinping since 2013. Many Chinese experts define this venture as the "Chinese version of the Marschal's plan." The authorities of this country have announced the creation of a special "Silk Road Fund" with a capital of about \$ 4 billion (pb.pl). The plans for "Silk Road" are presented in Figure 2.

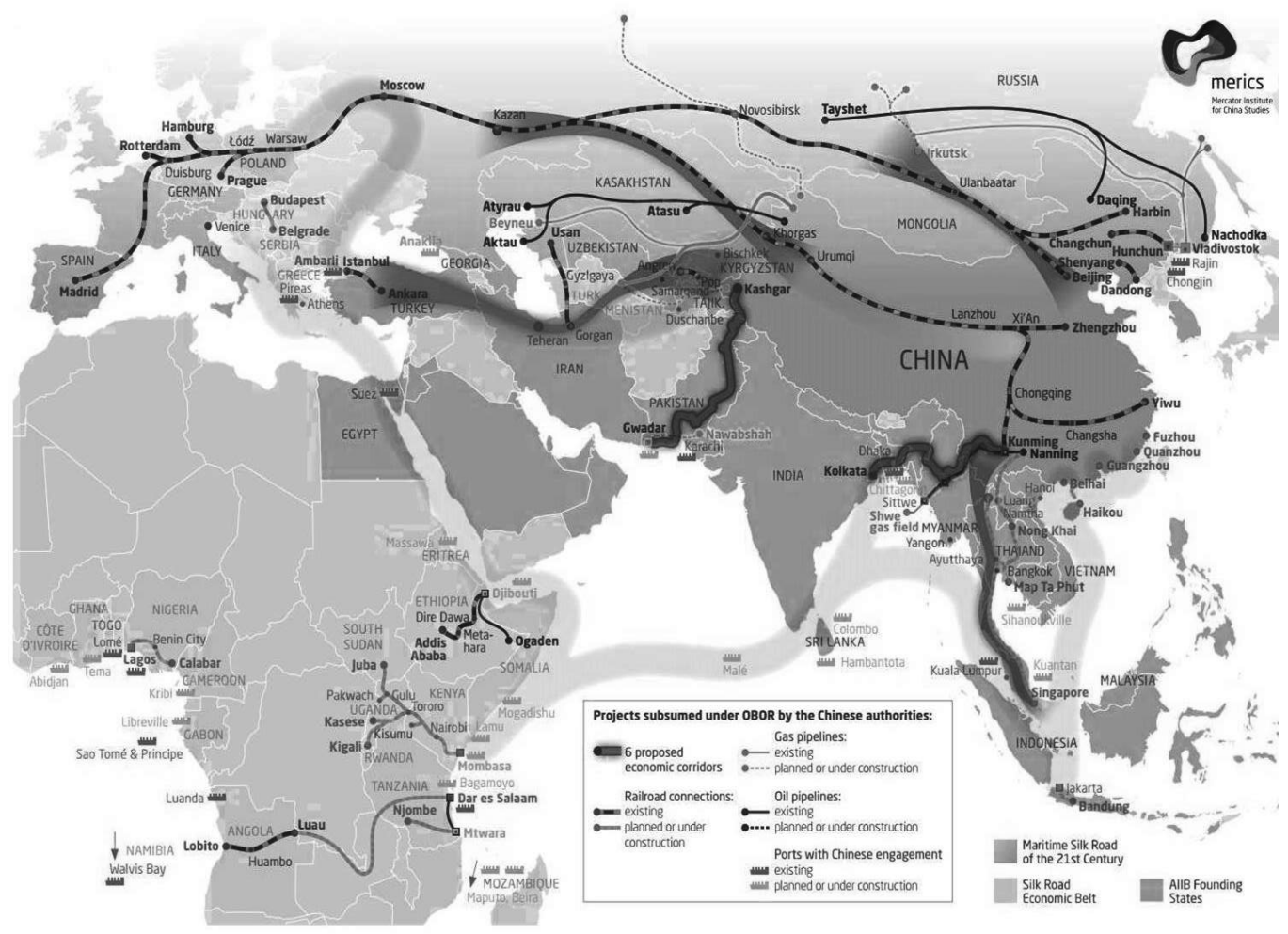

Figure 2. Land and sea route of the new "Silk Road"

Source: China-mapping, www.merics.org/en/merics-analysis/infographicchina-mapping/china-mapping/ (30.01.2016). 
The route is meant to be an alternative project to US domination in the world economy. This concept aims to legitimize and facilitate the growth of Chinese influence in transit countries on the way to Western Europe. Also in the western and central provinces of China the rout is to be a specific "driving force" for the development of the pro-export activities of many Chinese sub-regions. An additional supplement to this project is the Asian Infrastructure Investment Bank (AIIB) project set up by China with the participation of Poland and other countries.

Polish container hubs may play important role on this route, and particularly two of them:

1. Małaszewicze border terminal and the connection with Łódź Olechów terminal,

2. Broad-gauge line Hrubieszów - Sławków and Sławków terminal.

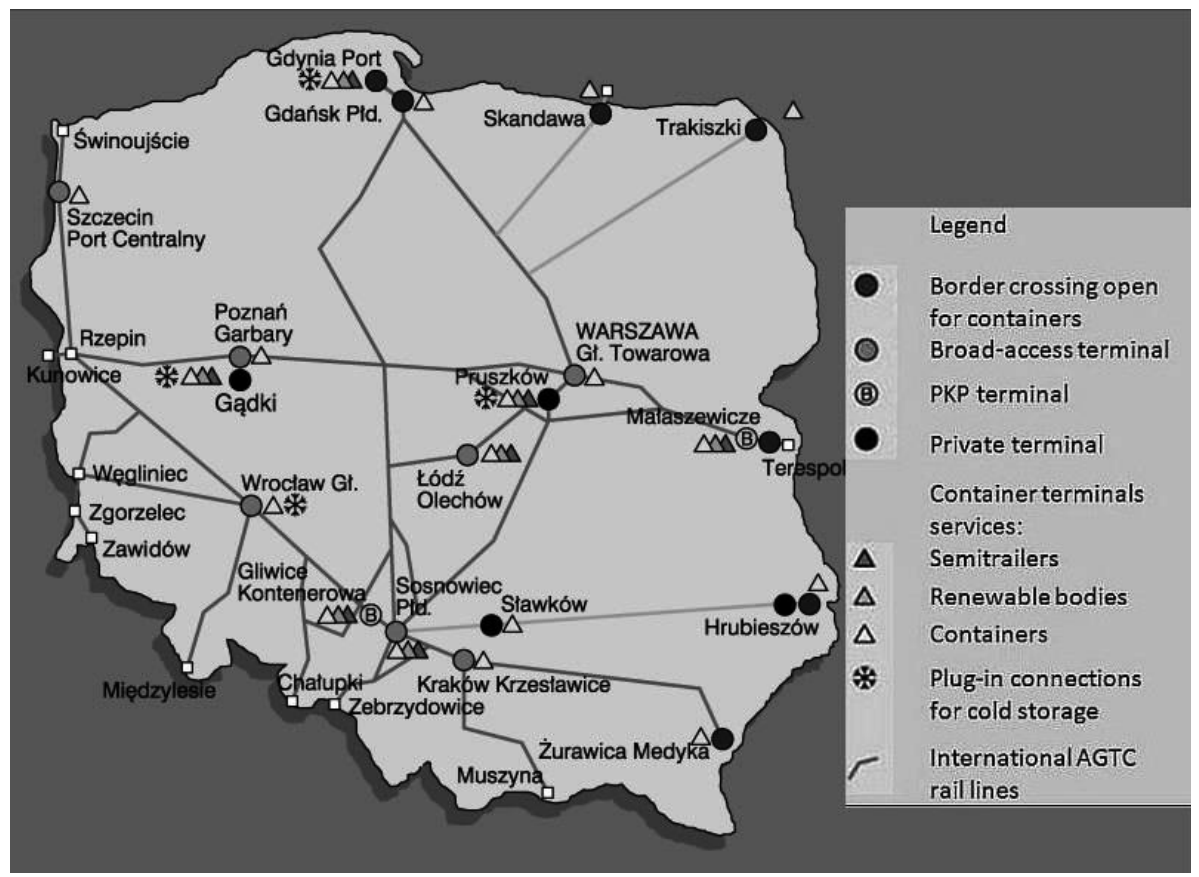

Figure 3. Map of Polish container terminals

Source: Transport intermodalny. Raport z pracy metodologicznej, GUS Warszawa 2016, p. 33.

Countries that want to support the "Silk Road" include Kazakhstan, Cambodia, Laos, Sri Lanka, Maldives, Poland, Lithuania, Israel, Austria, Greece, Afghanistan, Turkey, Indonesia, Egypt. On this route Poland can serve as the main hub at the western end of the route and the place for transit of Chinese export products to Central and Western Europe. The "Silk Road" route has a land and a sea version. In the land version (so called Route no. 1), the route begins in Zhengzhou, then Yiwu, Nanning through Urumgi, Kazan and Moscow to Lodz, Hamburg, Prague. The sea route (so called Route No. 2) starts from Harbin, then Beijing via Ulaanbaatar, Novosibirsk, Kazan, Moscow and further to Lodz, Prague, Hamburg and Rotterdam. The northern route (no. 1) is similar to the Trans-Siberian Railroad. 


\section{POLISH LAND TERMINALS IN CARGO FREIGHTS CHINA-EUROPE}

\section{THE OFFER OF SŁAWKÓW TERMINAL (NEAR DĄBROWA GÓRNICZA)}

Terminal Sławków is located at the end of the broad-gauge rail line $(1520 \mathrm{~mm})$. This terminal has perfected for many years its reloading, storage, spedition, logistics and customs offer. This terminal can reload semitrailers, replaceable bodies, loose cargo (coal, coke, charcoal), salt, grains, metallurgic goods, pig iron, glass, wood, boarded goods, goods packed in big bags. and chemical products.

Terminal Sławków has yearly reloading capacity in containers of 285000 TEU, 380000 of metallurgic goods, 200000 of palleted goods per year, 2 million tons of bulk cargo per year, and other bulk of 365000 per year. The contractors of reloading services can weigh the cargo on both truck or rail scales. They can also use the depots of 8500 square meters, 4860 square meters and one for 1760 pallets.

Sławków terminal has also good conditions for completing direct reload of cargo in 3 relations:

- broad-gauge rail trucks to normal rail trucks,

- normal rail trucks - road trucks,

- road truck-road truck.

Terminal Sławków has got a good location on the broad-gauge rails and can fulfill a role as reloading, logistics and spedition hub, and can help in activation of Polish export to Chinese market.

\section{THE OFFER OF ŁÓDŹ OLECHÓW TERMINAL}

The reloading hub in Łódź serviced by Spedcont has a chance to become important terminal in Poland that connects far east countries with western Europe (including also the "Silk Road").

Until recently the company Spedcont from Łódź has been associated only with container reloading. The company spotted the merits and perspectives of intermodal logistics development, and started their own rail connections, becoming intermodal operator with clearly set development path.

To use its potential in intermodal services, in February of 2017, Spedcont started the rail connection from Łódź terminal to ports of Gdańsk and Gdynia. The terminal has very good conditions for increasing the scale of its activities, and thus the number of connections grows every quarter of the year. Its role is no longer container reloading. Łódź-Olechów became important link in intermodal chain, with ambitions of becoming "the hub" for moving cargo from China and far East countries to many European countries and at the same time minimizing the costs of reloading and transport between terminals.

Spedcont's offer includes:

- spedition and transport of goods in rail containers in Poland and internationally,

- whole-train deliveries of containers from ports to terminals or the spur of the Client,

- full reloading services at Łódź terminal,

- carrying containers from Spedcont terminals by road trucks,

- transport with the use of Transsiberian railway and "Silk Road" in the future,

- safe spur transport within ports,

- safe and ecological transport of containers in Poland and abroad, 
- whole-train container shipments from Polish ports to own terminals or the spur of the Client,

- customs warehouse and storage in Łódź,

- door to door transport of containers by road trucks,

- customs clearance for export and import,

- faster and safer service of goods at the customs offices thanks to AEO certificate,

- other additional services.

Reloading potential of the Spedcont terminal in Łódź is as follows:

- number and lengths of railtracks: 2-1,400 meters,

- terminal area: 84,000 square meters,

- storage area: 42,800 square meters,

- storage capacity: 5,000 TEU, 4 levels,

- sorts of UTI for reloading and transport: Containers, semitrailers, replaceable bodies (www. spedcont.pl/oferta.html, 22.07.2017).

Spedcont has three reach-stackers for containers, two gantry cranes for containers and a 12 ton cart for reloading empty containers. This terminal has also power outlets for icehouse containers.

The company has recently developed international rail connections to terminal in Piacenza, Italy. The management of Spedcont is counting on developing this cooperation further. Goods from Łódź-Olechów travel also outside of Europe. Spedcont services direct connections with Mongolia, China, Kazachstan and Uzbekistan.

\section{THE OFFER OF RELOADING HUB IN GDAŃSK}

On the seas of the world, the Danish company Maersk Line is increasingly active. In May 2016, at the port of Gdansk S.A., Maersk Elba container ship moored with capacity of 13 thousand TEU containers. The ship is 366 meters long and $48 \mathrm{~m}$ wide. These types of ships can sail with cargo to Gdansk once a week.

A.P. Moller-Maersk Group also known as Maersk, is a Danish business conglomerate. It has activities in a variety of business sectors, primarily within the transport and energy sectors. It has currently $6 \%$ share in the world transportation of containers (Kęciek, 2011). Cargos of imports and exports are most often targeted at the Chinese ports of Ningbo, Shanghai and Yantian. On the way to and from Poland, these ships in Europe enter the ports of Le Havre (France), Felixt (England), Zeebrugge (Belgium), Gothenburg (Sweden), Rotterdam (Netherlands) and Gdansk (Poland).

The Port of Gdansk may also serve as a transshipment hub for smaller ships with transport to the Finnish and Russian ports. The current transshipment capacity of the port of Gdańsk exceeded one million TEU. Another very big ship on this line is Eleonora Maersk, with the capacity of carrying up to 14,770 containers. It is estimated that the value of containers placed on such vessels may exceed 1 billion Euro (in 2016 the port of Gdansk served 1299 thousand TEU, the port of Gdynia 612 thousand TEU and the port of Szczecin 90 thousand TEU).

A very important advantage of this type of vessels is the ability sail at the speed of 27 knots (with the economic speed of 24 knots). These ships are fully automated and the crew is very small, with only 13-20 employees. Despite the wide variety of containers transported by sea (including refrigerators), it is estimated that container ships, thanks to their large potential, serve around $88-90 \%$ of 
global transcontinental transport. These types of transport units, which are mostly built in Korean and Chinese shipyards, cost about \$ 190 million. DCT Gdansk terminal has numerous connections with Polish terminals such as Polzug-Poznań Gądki, PCC Intermodal - Kutno, Laconia Warsaw, Spedcont - Łódź, Maersk - Kąty Wrocławskie, Maersk - Sławków, Ost Sped - Szamotuły.

The port complex of the Tri-City ports has a very large trans-shipment potential: apart from the DCT Gdansk terminal, there also operate Baltic Container Terminal Gdynia (BTDG) and Gdynia Container Terminal (GTK). The total capacity of these terminals is expected to be approximately 5 million TEU in 2018. At many European and Polish container terminals attempts are being made to build completely automated terminals where human work will be limited to the minimum required (Krośnicka, 1990) (thanks to complex IT systems). Thanks to this complex computerization there can be achieved: shorter times of the container ships' stop in ports, increased day-to-day handling capacity and significant reduction in container handling costs.

\section{COMPETITION IN CARGO FREIGHTS BETWEEN RAIL AND SEA TRANSPORT}

Transport of international trade cargo between Asian and European countries is subject to competition between modes of transport, which are predestined for long-distance transport. There is a natural predisposition of maritime transport, which due to its main advantages: mass, relatively low operating costs, friendly relations with the environment, wins many competitions with other transport sectors. The current size of ships, their modern technology and relatively small crews make shipping from China, Korea, Singapore and India to Western and Central Europe being largely transported by the sea. The only drawback is the relatively long transport time of 30 to 40 days. An important advantage of this type of transport is the relatively favorable price for container shipping - in some shipowners it is \$1380-1630 for one TEU container.

Another important operator of long-distance transport of international trade from China to Europe may be the rail transport. Particular interest in this branch of transport stems from the idea of the "Silk Road", in which China, Russia, Kazakhstan, Ukraine, Poland and other countries see the opportunity to use the railway and take over part of the cargo from the sea. The trains can use a wide line $(1,520 \mathrm{~mm})$ LHS line to Sławków or through a passage in Malaszewicze (on tracks with a clearance of $1,435 \mathrm{~mm}$ ). These transhipments at border stations cause additional costs, increasing transit times. The advantage of the railway is the shorter delivery time of 14-20 days. However, the major disadvantage of this choice is the higher cost of transport, because rail freight is about $\$ 9,000$ per one TEU container.

China-Europe-China railways have a chance for further development. The current infrastructure on the Trans-Siberian Railway and the new routes of the "Silk Road" offer opportunities for the activation of intermodal transport in transit via Poland and the systematic growth of Polish foreign trade from Poland to China and neighbouring countries. There is observed a steady increase in traffic between China and Western Europe (which is about 12-15 million TEU), and there is also observed the demand for transport between Europe and China estimated at about 7-8 million TEU. Further forecasts predict that between 2016 and 2020 they may account for about 30-35\% of the total volume of cargo destined for transport in this route. These sectoral transfers and the greater share of railways in these services should occur due to the construction of modern rail and 
border infrastructure, favorable rates for access to railway infrastructure, efficient and effective means of railway transport for these services and the implementation of flexible prices, transportation quality and time according to the actual demand on the market.

\section{CONCLUSIONS}

The considerations contained in this article lead to the following conclusions:

1. Efficient and effective transport plays a very important role in the processes of globalization, integration and trade. These processes are conducive to increased inter-branch competition.

2. China, next to the EU (28), is a driving force in the world economy. China's turnover with Europe in 2016 was $\$ 3,899$ billion, with Poland constituting only $\$ 21.4$ billion.

3. Polish enterprises, trade organizations and the government of the Republic of Poland should take a special care to increase their exports of products and services to China through terminals in Gdańsk, Małaszewicze, Łódź and Sławków in order to better balance China and Poland's trade. 4. Land terminals in Małaszewicze, Sławków, Łódź and Gdańsk may contribute to the increase in Poland-China trade and have a role of reloading-logistics hub on the route of "Silk Road".

5. China's initial contribution to investment of the "Silk Road" is about $\$ 40$ billion in capital, and the creation of Asian Infrastructure Investment Bank (AIIB) - an initiative that was joined by Poland and many Asian and European countries.

\section{REFERENCES}

Godusławski, M. (2017). Made In Poland nie podbija Chin. Puls Biznesu, 30 stycznia.

Grzybowski M (2015). Transport morski LNG. Polska Gazeta Transportowa, 47, 8 listopada.

Kęciek, K. (2017). Giganty mórz. Pobrane z: www.tygodnikprzeglad.pl/giganty-morz/ (10.02.2017).

Krośnicka, K.A. (1990). Technologie w portach morskich. In: L. Mindur (ed.), Technologie transportowe. Warszawa: WKiŁ. Kuciński, K. (2002). Gospodarka globalna. Poznań: Kurpisz.

Lipińska-Słota, A. (2009). Korytarze transportowe Europa-Azja. In: M. Mindur (ed.), Transport Europa-Azja. WarszawaRadom: Instytut Technologii Eksploatacji.

Naisbitt, J. (2007). Megatrendy, dziesięć nowych kierunków zmieniających nasze życie. Poznań: Zysk i S-ka.

Nowy Jedwabny Szlak Chin szansa dla Polski na inwestycje i eksport. Pobrane z: www.pb.pl/nowy-jedwabny-szlak-chin-szansa-dla-polski-na-inwestycje-i-eksport-802881 (30.12.2016).

Perenc, J. (2013). Inwestycje w infrastrukturę bazy kontenerowej na Ostrowie Grabowskim jako szansa rozwoju transportu kombinowanego w PKP CARGO. Problemy Transportu i Logistyki, 22, 247-261.

Pluciński, M. (2013). Polskie porty morskie w zmieniającym się otoczeniu. Warszawa: CeDeWu.

Rosa, G. (2013). Konkurencja w transporcie. Warszawa: C.H. Beck.

Stiglitz, J. (2005). Globalizacja. Warszawa: Wydawnictwo Naukowe PWN.

Załoga, E (2013). Trendy w transporcie lądowym Unii Europejskiej. Szczecin: Wydawnictwo Naukowe Uniwersytetu Szczecińskiego. 


\section{SZANSE POLSKIEGO CONTEINERA TERMANALE DLA ŁADUNKÓW I USŁUG NA TRASIE CHINY- EUROPA-CHINY}

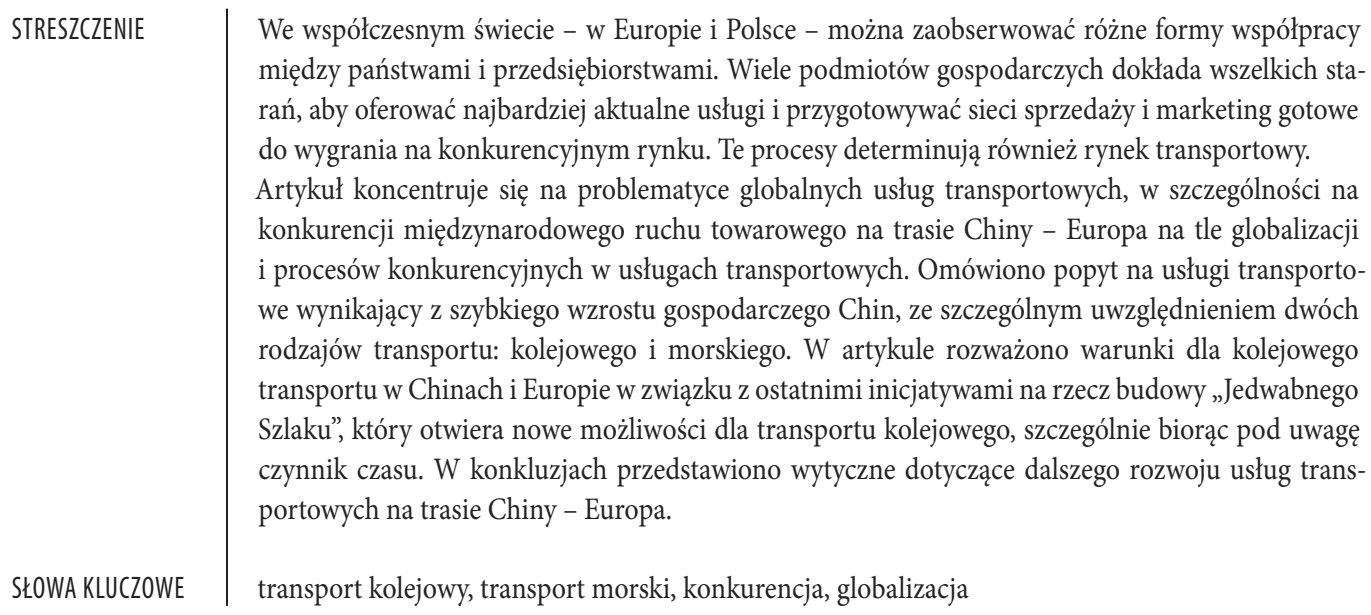

Translated by Józef Perenc 